\section{Science Identity among Latinx Students in the Biomedical Sciences: The Role of a Critical Race Theory-Informed Undergraduate Research Experience}

\author{
Tissyana C. Camacho, ${ }^{* *}$ Yolanda Vasquez-Salgado, ${ }^{*}$ Gabriela Chavira, ${ }^{*}$ \\ David Boyns, $\$$ Scott Appelrouth, $\$$ Carrie Saetermoe, and Crist Khachikian" \\ 'Department of Child and Adolescent Development, "Department of Psychology, sDepartment of \\ Sociology, and "Department of Civil Engineering, California State University, Northridge, \\ Northridge, CA 91330
}

\begin{abstract}
Underrepresented racial minority (URM) students in science, technology, engineering, and mathematics majors encounter educational, social, and structural challenges on the path toward their degrees and careers. An undergraduate research program grounded in critical race theory was developed and implemented to address this disparity. NIH BUILD PODER focuses on developing science identities in URM students through a culturally relevant and responsive research training environment, ultimately increasing their pursuit of biomedical-related research careers. The current study examines differences in science identities and the intention to pursue a science career among a sample of undergraduate Latinx seniors $(N=102)$ in biomedical science majors. Three groups were examined: 1$)$ BUILD PODER students, 2) non-BUILD PODER students who reported having a faculty mentor, and 3) non-BUILD PODER students who reported no faculty mentorship. Results revealed that BUILD PODER students reported the highest levels of science personal-identity and science social-identity upon graduation. Additionally, BUILD PODER students and nonBUILD PODER students with a mentor reported greater levels of science social-identity than those without a mentor. BUILD PODER students also reported the strongest intentions to pursue a science career after college. These results highlight the importance of identity processes in the success of Latinx college students in biomedical science majors.
\end{abstract}

\section{INTRODUCTION}

Over the past decade, there has been growing concern about the United States' ability to maintain a leading role in global economic markets where science, technology, engineering, and mathematics (STEM) disciplines play an important role. In addition to this concern, there are also disparities about who composes the STEM workforce. According to a recent National Science Foundation (NSF, 2019) report, 21\% of people ages 18-64 in the United States identify as Latinx. However, they make up only 13\% of all STEM bachelor's degrees awarded and 8\% of the STEM workforce. If left unaddressed, these disparities will grow when considering that, by 2060, individuals of Latinx descent will account for approximately $28 \%$ of the total U.S. population (U.S. Census Bureau, 2018). Research has found that underrepresented racial minority (URM) students in STEM majors, including Latinx students, are more likely than other students to drop out of STEM majors (Chang et al., 2014; Baird et al., 2016).

URM undergraduates encounter many challenges on the path toward their STEM degrees, including but not limited to: 1) limited academic preparation (Chang et al., 2014; Dika and D'Amico, 2016; Katrevich and Aruguete, 2017); 2) a lack of same-race peers and faculty members (Strayhorn et al., 2013); 3) a lack of faculty contact and faculty mentorship (Chang et al., 2014; Katrevich and Aruguete, 2017); 4) a lack of
Graham F. Hatfull, Monitoring Editor Submitted Jul 9, 2019; Revised Feb 24, 2021; Accepted Mar 4, 2021

CBE Life Sci Educ June 1, 2021 20:ar23 DOI:10.1187/cbe.19-06-0124

*Address correspondence to: Tissyana C. Camacho (tissyana.camacho@csun.edu). (c) 2021 T. C. Camacho et al. CBE-Life Sciences Education @ 2021 The American Society for Cell Biology. This article is distributed by The American Society for Cell Biology under license from the author(s). It is available to the public under an Attribution-Noncommercial-Share Alike 3.0 Unported Creative Commons License (http://creativecommons.org/licenses/ by-nc-sa/3.0).

"ASCB $®$ " and "The American Society for Cell Biology $\circledR^{\prime \prime}$ are registered trademarks of The American Society for Cell Biology. 
emotional support and encouragement from family members (Cole and Espinoza, 2008; Chang et al., 2014); 5) financial concerns preventing them from participating in research (Hurtado et al., 2008); and 6) a lack of validation and recognition from "meaningful scientific others" that they are scientists (Carlone and Johnson, 2007). Given these challenges, it is critical to identify factors that can promote Latinx college students' success in pursuing STEM disciplines. One such promotive factor is science identity-the personal feeling that they are scientists (science personal-identity) and that others see them as scientists (science social-identity; Kim et al., 2018; Thompson and Jensen-Ryan, 2018).

\section{Science Identity}

Throughout their lifespans, individuals derive self-worth and value from their various social identities (Tajfel, 1981). These social identities can be centered around gender, religion, race, ethnicity, and even occupation. The feelings surrounding our various social identities are important, because they relate to psychological well-being. Individuals have an innate need to belong to social groups, as well as an innate need to be able to positively frame such social groups (and not to be involved in negative groups; Tajfel, 1981). Social identities are made up of several facets related to group membership and social categorization. For example, one's identity can reflect how important a social categorization (e.g., gender, ethnicity) is in defining one's overall self-concept (also known as importance to identity or centrality; Luhtanen and Crocker, 1992; Sellers et al., 1998), how positively or negatively one feels about one's own group membership (also referred to as public collective self-esteem or private regard; Luhtanen and Crocker, 1992; Sellers et al., 1998), and how one believes others perceive one's group membership (e.g., public collective self-esteem or public regard; Luhtanen and Crocker, 1992; Sellers et al., 1998).

Decades of identity research have revealed that identities are fundamental sources of motivation and are composed of processes related to both personal identification and social identification (Tajfel and Turner, 1986; Luhtanen and Crocker, 1992; Sellers et al., 1998; Ellemers et al., 2002; Brewer and Hewstone, 2004; Stets et al., 2017; Kim et al., 2018). Personal identities are those that characterize how individuals conceptualize themselves. Social identities tie individuals to social categories and the groups to which they belong. Though personal and social identities are related, each uniquely contributes to self-concepts and social relationships. In this study, we examine two different, albeit related, types of science identities: science personal -identity and science social-identity. While prior research on science identity, particularly among URM students, may not investigate or distinguish between the different facets of science identity, it is important to investigate the nuance of such work. We posit that identity processes can be leveraged to increase the persistence and representation of Latinx scientists. To do so, we must examine science identity at its different levels (i.e., science as it relates to the self and science as it relates to others).

Personal identities serve to facilitate self-assessments that are important motivations for behavior, academic achievement, and career aspirations (Burke and Hoelter, 1988). Through connections to groups, social identities provide students with the motivation and confidence to seek new roles and role models, overcome stereotypes, and transcend social inequities (Fuligni,
2007). Combined, personal and social identities can shape a student's educational experience and decision to pursue a career in science. Research has found that science identity is an important factor in students' intention to pursue a STEM career (Merolla et al., 2012) and actually pursuing a STEM career (Carlone and Johnson, 2007; Stets et al., 2017). Thus, intervening on science identity is likely a worthwhile pursuit, and an ideal intervention opportunity may be during undergraduate Latinx students' participation in research.

For youth enrolled in college, these years will be critical for exploring and making sense of who they are-that is, their identity (Arnett, 2000). A primary consideration throughout college will be their identity with regard to their future occupation (Arnett, 2014). Thus, college is a time where one's identity as a scientist can begin, be further developed, or be diminished. Indeed, science identity shows changes throughout the college years (Robinson et al., 2018, 2019). Furthermore, research demonstrates that science identity is predictive of one's choice to major in the sciences (Robinson et al., 2019), the commitment to a science career (Chemers et al., 2011; Estrada et al., 2011; Merolla et al., 2012; Byars-Winston and Rogers, 2019), entrance into a graduate science program (Merolla and Serpe, 2013), and post-graduation employment as a scientist (Stets et al., 2017; Robinson et al., 2018).

\section{Latinx College Students as Scientists}

Despite Latinx students' interests in STEM fields, fewer than predicted complete a STEM degree (NSF, 2019), and identification as a scientist is lower than in other racial-ethnic groups (Hazari et al., 2013; Lu, 2015). For example, Lu (2015) described multiple challenges for first-year Latino males in college, including academic underperformance lowering their science competencies and a perception that the scientific community is elitist and challenging to enter. Furthermore, some Latinx students experience a "disconnect" in course performance whereby they may not know that they are in academic trouble until it is too late in the term (Lu, 2015).

Research on the persistence of URM students in science reveals that it is crucial for students to develop a science identity and see themselves as scientists (Carlone and Johnson, 2007; Chemers et al., 2011; Merolla et al., 2012; Jackson and Suizzo, 2015). Stets et al. (2017) found that URM students held strong intentions to pursue a science career in a national longitudinal panel study of 1420 participants in a National Institutes of Health-funded undergraduate research training programs for URM students. They also found that science identities positively impacted the likelihood that URM students would later enter a science profession. Similarly, in a large sample of ethnically diverse members of an organization dedicated to fostering the success of Latinx and Native Americans in STEM fields, Chemers et al. (2011) found that science identity was a strong predictor of commitment to science careers for undergraduate, graduate, and postdoctoral education levels. In a sample of young Latina girls, Avila (2019) found that actively participating in scientific activities and writing about themselves as scientists cultivated a science identity. Jackson and Suizzo (2015) found that, for Latina STEM undergraduate students, educators and families were critical in creating an environment that fostered a science identity. Thus, throughout the educational pipeline, Latinx 
students benefit from programs and experiences that encourage science identity development.

The importance of science identity for these meaningful academic and career outcomes suggests that intervening in science identity development may be a worthwhile and influential pursuit, particularly for URM students such as Latinxs. Helping students feel that they are scientists and belong in a scientific community is essential to Latinx student scientists' success and growth. Such interventions can take the form of summer bridge programs, course curricular development, service-learning opportunities, or even undergraduate research experiences.

The benefits of participating in undergraduate research experiences in recruiting, retaining, and graduating URM students in STEM majors are well known (Schultz et al., 2011; Slovacek et al., 2012; Hernandez et al., 2013, 2018). These undergraduate research experiences, particularly in STEM, regularly include components such as financial support, hands-on experience with research, additional exposure to the STEM disciplines, professional development, and faculty mentoring (Chemers et al., 2011; Rincon and George-Jackson, 2016). However, the education and culture within science departments and research labs often align with masculine and White cultural norms and values, such as gateway "weed-out" courses and unfriendly or unapproachable professors (Seymour and Hewitt, 1997; Carlone and Johnson, 2007). These features make STEM undergraduate research experiences challenging for URM students, resulting in less favorable outcomes such as leaving research labs, the STEM major, or college altogether (Seymour and Hewitt, 1997; Carlone and Johnson, 2007; Stephens et al., 2012; Thompson and Jensen-Ryan, 2018). Furthermore, too often, URM students comment about being "the only one" in science and math classroom settings, which "entails the burden of representing the race and is accompanied by feelings of isolation" (Malone and Barabino, 2008, p. 486). This sense of being the "only one" may also adversely affect their participation in scientific settings.

One challenge for the scientific community is the development of rigorous undergraduate training programs that increase preparedness and a sense of belonging among all participants while also addressing social and cultural factors that can increase persistence rates for individuals from URM groups. Our program, BUILD PODER (Building Infrastructure Leading to Diversity, Promoting Opportunities for Diversity in Education and Research), addresses this gap. BUILD PODER is an undergraduate research experience with the rigor of traditional programs (see Rincon and George-Jackson, 2016) that also explicitly addresses structural, cultural, and gender inequities in science and honors cultural and gendered identities for URM students within a critical race theory (CRT) framework (Saetermoe et al., 2017).

\section{The Program}

BUILD PODER's central innovation and its transformative power lies in its CRT foundation. CRT is rooted in the Civil Rights and critical legal studies movements of the 1960s and 1970s (Bell, 1995) and "critically interrogate[s] how the law reproduces, reifies, and normalizes racism in society" (López, 2003, p. 83). The five tenets of CRT that form its central perspective, pedagogy, and research methodology are: 1) the centrality of race and racism; 2) the challenge to dominant ideology; 3) an interdisciplinary perspective; 4) the importance of experiential knowledge; and 5) a commitment to social justice (Solórzano et al., 2000; Solórzano and Yosso, 2002).

Bensimon and Dowd (2012) argue that institutional transformation needs to address the structural and institutional problems that have created disparities for students from URM communities. Additionally, Serki (2018) argues that the use of CRT in science education "would help illuminate and perhaps eradicate practices within science classrooms that perpetuate the status quo by subjugating the voices, experiences, and knowledge of students of color" (p. 98). Thus, at the broadest level, BUILD PODER unites students and faculty around biomedical research questions while contextualizing and developing these research questions around issues of social justice. The merging between research and social justice cultivates cultural coherence between our culturally diverse students' backgrounds and their STEM research experiences.

BUILD PODER, funded by a grant from the National Institutes of Health (NIH), has developed CRT-informed training for faculty mentors and students from various underrepresented communities to foster science identities and increase their interest in pursuing research careers related to the biomedical sciences. By employing CRT in the development of undergraduate student research training, we have moved beyond merely documenting inequities to genuinely understanding and challenging the power hierarchies that undergird them to empower students along their biomedical academic paths. BUILD PODER was founded with the idea that the best way for URM students to pursue biomedical research careers is to engage in well-designed, hands-on scientific inquiry in collaboration with well-trained, culturally responsive faculty mentors and peers. Faculty mentors receive training to "teach students how to navigate the cultures and discourses" of the biomedical sciences and be successful interacting in professional networks (Bensimon and Dowd, 2012, p. 3). Based on a CRT framework, BUILD PODER addresses race and intersectionalities (Crenshaw, 1990) by providing a curriculum directed at transparency, respect, and correcting the historical abuses in science. Students experience rigor by: 1) participating in an intensive 4-week entry-to-research training program, 2) working year-round in a biomedical research laboratory, 3) taking advanced research methods courses, 4) enrolling in CRT-informed professional development courses, and 5) participating in group-based activities that create a sense of belonging and excitement of being a scientist and scholar. Each of the five tenets of CRT can be empirically measured and evaluated through training modules. Table 1 demonstrates student and faculty activities for each of the five CRT tenets. Below is one CRT tenet and examples of its implementation within student training. Saetermore et al. (2017) provide a more in-depth review of CRT and BUILD PODER, and an argument for the importance of critical mentorship is available in Vargas et al. (2020).

Centrality and Intersection of Race and Racism. In summer training and throughout the academic year, training modules and discussions on racism, sexism, and other forms of discrimination occur in BUILD PODER. We introduce students to the importance of cultural diversity in the sciences, implicit biases and prejudice in the forms of gender and racial microaggressions (Solórzano et al., 2000) and macroaggressions (Jones et al., 2010; van Ryn et al., 2015), impostor phenomenon 
TABLE 1. CRT tenets and related student and faculty sample activities

\begin{tabular}{|c|c|c|}
\hline CRT tenet & Student activity & Faculty activity \\
\hline $\begin{array}{l}\text { Centrality of race } \\
\text { and racism }\end{array}$ & $\begin{array}{l}\text { Research ethics training: a focus on historical ethical } \\
\text { violations on communities of color and other } \\
\text { marginalized communities, beginning with a discussion } \\
\text { on eugenics }\end{array}$ & $\begin{array}{l}\text { Entry mentor training: } 16 \text { hours of "CRT Light" with } \\
\text { introduction to unconscious bias and privilege, } \\
\text { microaggressions and affirmations, stereotype threat, } \\
\text { self-reflection }\end{array}$ \\
\hline $\begin{array}{l}\text { Challenge to dominant } \\
\text { ideologies }\end{array}$ & $\begin{array}{l}\text { Summer Jump Start (SJS) program provides education, } \\
\text { activities, and specific methods of countering racism in } \\
\text { academe, challenging beliefs about intelligence and } \\
\text { who is a "scientist" }\end{array}$ & $\begin{array}{l}\text { Critical White awareness group reading White history and } \\
\text { consciousness-raising and critical authors of color } \\
\text { (Michelle Alexander, Eduardo Bonilla-Silva, Ibram X. } \\
\text { Kendi, Ta-Nehisi Coates) }\end{array}$ \\
\hline $\begin{array}{l}\text { Experiential } \\
\text { knowledge }\end{array}$ & $\begin{array}{l}\text { SJS heritage report: students understand their cultural } \\
\text { inheritance and the importance of using their } \\
\text { knowledge in the sciences by interviewing elders in } \\
\text { their family who are keepers of knowledge }\end{array}$ & $\begin{array}{l}\text { Mentor training year 4: Theatre of the Oppressed (Boal) } \\
\text { with Master of Social Work students' experiences, } \\
\text { problematizing and role-playing around discrimination } \\
\text { in the sciences }\end{array}$ \\
\hline
\end{tabular}

(Cokley et al., 2013, 2015; Peteet et al., 2015), and stereotype threat (Steele, 1995, 1997; Jones et al., 2010). Students also learn strategies to deal with, overcome, and cope with these potential barriers and prejudices. Each module and workshop contains references to literature that highlights the intersection between racism and the sciences (e.g., van Ryn et al., 2015). These modules also include discussions about recognizing and highlighting what students can do when experiencing a microaggression.

Selection of BUILD PODER Trainees. BUILD PODER trainees are selected into the program using the following inclusionary criteria: 1) a current or transferring undergraduate California State University, Northridge (CSUN) student; 2) full-time enrollment status; 3) majoring in a STEM field relevant to biomedical science (e.g., biology, biochemistry, psychology, public health); 4) a grade point average greater than 3.0 ; 5) U.S. citizen or noncitizen nationals or permanent residents; 6) traditionally underserved underserved minority groups, persons with disabilities, or economically disadvantaged students; and 7) completion of at least 30 units of college-level courses and at least a 2-year commitment to the program.

\section{The Current Study}

The purpose of this study was to investigate whether engagement in a CRT-informed undergraduate research experience aids Latinx students in feeling like a scientist (i.e., science personal-identity), belonging to the field of science (science social-identity), and strengthening their intention to pursue a science career. We examined three groups of Latinx students in biomedical science majors: 1) students in BUILD PODER, an undergraduate research experience that encompasses research and cultural empowerment training, as well as mentorship with a well-trained, culturally responsive faculty mentor (see Vargas et al., 2020); 2) students not in BUILD PODER who report having faculty mentorship; and 3) students not in BUILD PODER and without faculty mentorship. The two hypotheses were as follows:
1. Latinx biomedical undergraduates in BUILD PODER will report higher levels of science personal- and social-identity and stronger intentions to pursue a science career than Latinx biomedical undergraduates not in BUILD PODER.

2. Latinx biomedical undergraduate students with faculty mentorship will report higher science personal- and social-identity and stronger intention to pursue a science career than those without faculty mentorship.

\section{METHOD \\ Participants}

A total of 102 college seniors (79 women, 23 men) who self-identified as Latinx participated in the current survey study. All participants were currently enrolled at CSUN, a large public 4-year university in Southern California. The participants completed an exit survey based on their designations as graduating seniors in majors related to the biomedical sciences. The graduating seniors were, on average, 23.44 years old $(S D=2.10)$. Seventy-eight percent received a federal Pell Grant (a standard proxy for low-income status), and $83.3 \%$ reported being the first in their immediate families to attend college (i.e., first-generation college students). Within the 102 participants, we examined three student groups: 1) students who spent at least 2 years in BUILD PODER (a faculty-mentored research experience, $n=42$ ), 2) students not in BUILD PODER who reported having a faculty mentor $(n=21)$, and 3$)$ students not in BUILD PODER who reported no faculty mentorship $(n=39)$. We refer to these groups as 1) BP, 2) NonBP+M, and 3) NonBP-M, respectively. Demographic data (i.e., gender, age, Pell Grant status, and first-generation college student status) are provided for the three groups separately in Table 2.

\section{Design and Procedure}

The exit survey was an online survey administered through Qualtrics, a Web-based survey tool, and solicited information regarding the students' educational experiences at our institution. A total of 48 Latinx BUILD PODER trainees who were 
TABLE 2. Demographics by student group

\begin{tabular}{lccc}
\hline & BP & NonBP+M & NonBP-M \\
\hline$N$ & 42 & 21 & 39 \\
M age (SD) & 24.21 & 23.00 & 22.85 \\
& $(3.03)$ & $(0.78)$ & $(0.63)$ \\
\% Pell Grant recipients & $76 \%$ & $81 \%$ & $80 \%$ \\
\% first-generation students & $81 \%$ & $95 \%$ & $80 \%$ \\
\% Female & $79 \%$ & $81 \%$ & $74 \%$ \\
\hline
\end{tabular}

graduating seniors were invited to participate in the senior exit survey; 42 completed the survey ( $87.5 \%$ response rate). Of the 42 participants in BUILD PODER, 20 had data from the Freshman Survey-a national survey of incoming first-year students' pre-college experiences and expectations for college at fouryear colleges, administered by the Higher Education Research Institute (HERI) and Cooperative Institutional Research Program (CIRP). The remaining BUILD PODER students $(n=22)$ were community college transfer students, as community college students represent a large body of upperclass students at California State Universities; consequently, the Freshman Survey data are unavailable for these students.

For the comparison groups-students who were not in BUILD PODER (NonBP+M and NonBP-M)-the university's Office of Institutional Research created a pool of 300 participants to contact. These participants were randomly selected based on: 1) a major in the biomedical sciences, 2) self-identifying as Latinx, and 3) prior completion of the Freshman Survey. All 300 students received email invitations, and responses were capped at 60 students. The 60 -participant cap reflects the amount allotted for incentives, as well as an appropriately sized comparison group (to BUILD PODER's 42 students). All participants provided informed consent before beginning the survey, and those who completed the exit survey were compensated with a $\$ 20$ Amazon gift card. We obtained university Institutional Review Board approval.

\section{Measures}

Science Personal-Identity. The first construct of science identity in our independent exit survey consisted of a composite score of three items obtained from the HERI and CIRP's College Senior Survey (see Estrada et al., 2011; Berdan Lozano and Tilman, 2016). The measure asked students to respond to the prompt, "To what extent do you agree that the following statements are true of you" for three items: 1) "I have a strong sense of belonging to a community of scientists," 2) "I think of myself as a scientist," and 3) "I feel like I belong in the field of science." Response options ranged from 1 (strongly disagree) to 5 (strongly agree). Cronbach's alpha for this measure was 0.93 .

Science Social-Identity. The second construct of science identity consisted of a composite score of three items from the Freshman Survey (e.g., Eagan et al., 2017; Stolzenberg et al., 2019). The measure asked students, "Please indicate the importance to you personally of each of the following" for the following three items: 1) "becoming an authority in my field," 2) "obtaining recognition from my colleagues for contributions to my special field," and 3) "making a theoretical contribution to science." Response options ranged from 1 (not important) to 5 (essential).
Science social-identity data for first-year students were obtained through the Freshman Survey. Our independent exit survey also included the same three items. Cronbach's alpha for this measure was 0.67 for first-year students and 0.78 when assessed during the senior year. ${ }^{1}$ Previous research studies examining these items among first-year students yielded similar Cronbach's alpha values (e.g., 0.71 in Chang et al., 2011; 0.67 in Chang et al., 2014).

Science Career Intention. The intention to pursue a science career in our independent exit survey consisted of a single question stemming from the College Senior Survey (Berdan Lozano and Tilman, 2016). The question asks: "Will you pursue a science-related research career?" Response options ranged from 1 (definitely no) to 5 (definitely yes).

Mentorship. For the students who did not participate in BUILD PODER, mentorship was assessed by a single question in our independent exit survey. The question states, "Did you have an academic mentor at CSUN?" Students who responded "yes" to this question were designated in the NonBP+M group. Students who responded "no" to this question were designated in the NonBP-M group.

\section{Analysis Strategy}

We examined mean score differences in our dependent variables (i.e., science personal-identity, science social-identity, and science career intentions) among the three student groups of interest. Data were analyzed in SPSS using one-way analyses of variances (ANOVA) using eta-squared $\left(\eta^{2}\right)$ to measure effect sizes. Each ANOVA model included Bonferroni correction post hoc tests to examine significant mean differences among the three student groups (corrected to an alpha level of 0.05 in SPSS).

\section{RESULTS}

\section{Preliminary Analyses}

To account for potential differences within our BUILD PODER group (i.e., the 22 transfer students vs. the 20 who began CSUN as first-time first-year students), we conducted $t$ tests on each dependent variable. No significant differences emerged within the BUILD PODER group. Students who transferred from a community college and those who began as first-year first-time students did not report different levels of: 1) science personal-identity, $t(40)=-0.03, p=0.976 ; 2)$ science social-identity, $t(40)=-0.34, p=0.736$; or 3$)$ science career intentions, $t(40)$ $=-1.66, p=0.106$.

Responses to items investigating science (social) identity in the Freshman Survey were analyzed to account for the possibility of initial differences in science (social) identity. All participants in the comparison groups (NonBP+M and NonBP-M) had the Freshman Survey data, as that was a criterion for inclusion in the study. Of the 42 BUILD PODER participants, 20 had the

\footnotetext{
${ }^{1}$ It is worth noting the change in Cronbach's alpha from first-year (0.67) to senior year (0.78). From a student development perspective, particularly regarding science identity, these items may seem obscure at the beginning of college. However, it seems that, with time, experience, and knowledge, a greater understanding of these concepts makes these items less ambiguous. Thus, these concepts hang together more clearly after four years of college.
} 


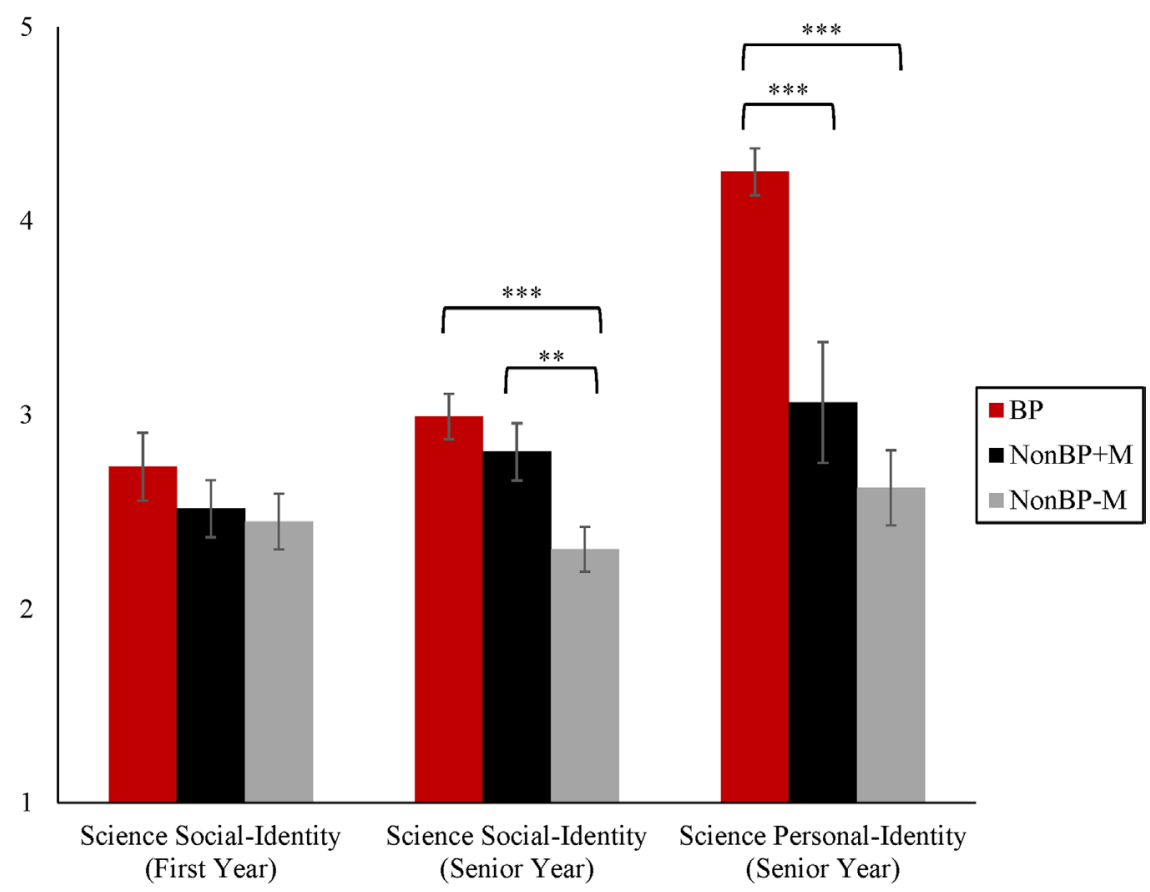

FIGURE 1. Mean scores on science personal-identity and science social-identity by group. ${ }^{* *} p<0.01 ; * * * p<0.001$.

Freshman Survey data (as they began as first-time first-year students). A comparison of the three groups through a one-way ANOVA revealed that no significant differences were found in science social-identity as first-time first-year students, $F(2,74)$ $=0.83, p=0.441, \eta^{2}=0.02$ (see Figure 1 ). Therefore, all students in this study - regardless of grouping — are assumed to be equal in their views and feelings surrounding science in their first year of college.

\section{Science Personal-Identity}

There was a statistically significant difference in science personal-identity among the three graduating senior groups as determined by a one-way ANOVA, $F(2,99)=23.06, p<0.001$, $\eta^{2}=0.32$. Post hoc tests using the Bonferroni correction revealed that students in the BP group reported significantly greater science personal-identity $(\mathrm{M}=4.25, \mathrm{SE}=0.12)$ than the NonBP+M group $(\mathrm{M}=3.06, \mathrm{SE}=0.31, p<0.001)$ and the NonBP-M group $(\mathrm{M}=2.62, \mathrm{SE}=0.19, p<0.001)$. There was no significant difference between the NonBP+M group and the NonBP-M group ( $p=0.436$; see Figure 1 ). Thus, the hypothesis that BUILD PODER students would report a greater science personal-identity than the non-BUILD PODER students (with or without a mentor) was supported. The findings did not support the second hypothesis that the non-BUILD PODER students with a mentor $(\mathrm{NonBP}+\mathrm{M})$ would report greater science personal-identity than those without a mentor (NonBP-M). There were no differences in science personal-identity between the non-BUILD PODER student groups, regardless of their mentoring status. These findings suggest that the CRT-informed BUILD PODER fosters an environment for Latinx students to develop greater self-perception of being a scientist.

\section{Science Social-Identity}

At the end of college, a statistically significant difference in science social-identity emerged among the three groups as determined by a one-way ANOVA, $F(2,99)=$ 9.30, $p<0.001, \eta^{2}=0.16$. Post hoc tests using the Bonferroni correction revealed that students in the BP group ( $\mathrm{M}=2.99$, $\mathrm{SE}=0.12$ ) reported a significantly greater science social-identity than students in the NonBP-M group $(\mathrm{M}=2.31, \mathrm{SE}=0.12, p<$ 0.001 ), but not students in the NonBP+M group $(\mathrm{M}=2.81, \mathrm{SE}=0.15, p=1.00)$. Additionally, a statistically significant difference emerged between the non-BUILD PODER groups. Students in the NonBP+M group reported greater social science identity than students in the NonBP-M group ( $p=0.004$; see Figure 1).

Thus, the hypothesis that BUILD PODER students would report a greater science social-identity than the non-BUILD PODER students (with or without a mentor) was partially supported. BUILD PODER students reported a greater science social-identity only when compared with non-BUILD PODER students without mentors. The findings supported the second hypothesis that the non-BUILD PODER students with a mentor would report greater science social-identity than those without a mentor. These findings suggest that having a faculty mentor can help Latinx students feel that they are and will be seen by others as scientists. Therefore, mentors facilitate the social perception that they are scientists, as those without a program and mentor reported the lowest social science identity (see Figure 1).

\section{Science Career Intention}

For the intention to pursue a science career, there was a statistically significant difference among the three groups as determined by a one-way ANOVA, $F(2,99)=17.02, p<0.001, \eta^{2}=$ 0.26 . Post hoc tests using the Bonferroni correction revealed that students in the $\mathrm{BP}$ group $(\mathrm{M}=4.45 \mathrm{SE}=0.12)$ reported a significantly greater intention to pursue a science career than students in the NonBP+M group $(\mathrm{M}=3.24, \mathrm{SE}=0.30, p<$ $0.001)$ and students in the NonBP-M group $(\mathrm{M}=3.03, \mathrm{SE}=$ $0.22, p<0.001)$. A significant difference did not emerge between students in the non-BUILD PODER groups $(p=1.00$; see Figure 2). Thus, the hypothesis that BUILD PODER students would report a greater intention to pursue a science career than the non-BUILD PODER students (with or without a mentor) was supported. The findings did not support the second hypothesis that the non-BUILD PODER students with a mentor would report a greater intention to pursue a science career than those without a mentor. There were no differences in science career intention between the non-BUILD PODER student groups, regardless of their mentoring status. These findings suggest that a CRT-informed undergraduate research experience can be an important factor for increasing the confidence and intention of pursuing a science-related career among Latinx students majoring in biomedical sciences. 


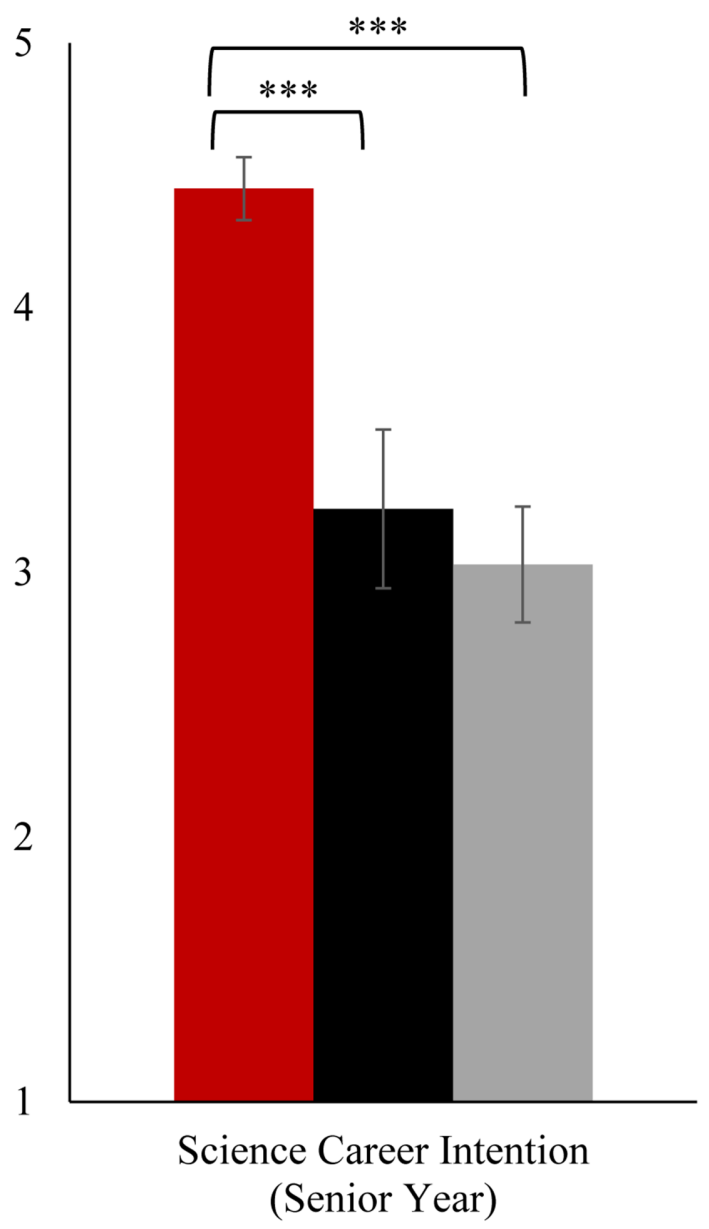

\section{- $\mathrm{BP}$ NonBP+M $\backsim$ NonBP-M}

FIGURE 2. Mean scores on science career intention by group. $* * * p<0.001$.

\section{DISCUSSION}

The current study demonstrates that a CRT-informed undergraduate research experience can influence Latinx students' science identity in two overlapping, but different, science identity domains (personal-identity and social-identity). This study also highlights Latinx students' intentions to pursue a science-related career and how undergraduate research experiences can shape such intentions. The analysis using data obtained from the Freshman Survey revealed no differences in science social-identity during the first year of college between students who eventually joined BUILD PODER compared with the non-BUILD PODER groups with a mentor $(\mathrm{NonBP}+\mathrm{M})$ and without a mentor (NonBP-M). Therefore, we are confident that the experience in BUILD PODER largely influenced the observed differences in the various outcomes as graduating seniors. We believe that the evidence we provide will promote a new way of thinking in integrating culture, social justice, empowerment, and theory in undergraduate research experiences for Latinx students, which may be translated to URM students more broadly.

\section{Science Personal-Identity and Science Social-Identity}

The findings revealed that Latinx students in BUILD PODER reported a higher science personal-identity than both the nonBUILD PODER groups (with and without a mentor), supporting the use of CRT-informed programs. A CRT-informed research program should provide an enriched curricular experience centered on building a sense of belonging to the scientific field, with particular acknowledgment of the potential barriers (e.g., racism) that URM students may encounter as emerging scientists. Through a research experience addressing underrepresented and marginalized identities, students learn about the role of racism, sexism, and other prejudices, specifically in the context of science. Students come to understand that minimal representation in science is not an individual or group failure. Rather, it is inequities at several levels of science that create such a lack of representation. Thus, students can positively reframe their personal esteem about their in-group, a necessary component for social identity overall (Tajfel, 1981; Tajfel and Turner, 1986). That is, by learning about the inequities and disparities in science through the lens of CRT, students become informed, included, and empowered. This knowledge allows URM students to reframe themselves as scientists, instead of being made to believe that they are a part of a group incapable of being in the sciences.

In addition, we found that Latinx students in BUILD PODER reported a greater science social-identity than the non-BUILD PODER group without a mentor, but not compared with the nonBUILD PODER group with a mentor. This finding suggests faculty mentorship can play a crucial role in one aspect of science identity by supporting the perception that others view a student as a scientist. Such perception is a critical component of feeling that one is a scientist. Carlone and Johnson (2007) found that URM women in science experienced a less arduous process of developing a science identity when they received validation and recognition from "meaningful scientific others." As such, faculty mentors may play a pivotal role in assisting students in feeling that they are emerging scientists (Thiry and Laursen, 2011) and prevent the "pushout" of URM students (Vargas et al., 2020). Thus, for the Latinx students in our sample, the process of having a faculty mentor who serves as a role model and guide and receiving recognition from that mentor may be the avenue that socially engages Latinx students in science (Carlone and Johnson, 2007; Thiry et al., 2011; Jackson and Suizzo, 2015). Such mentorship is what gets students to think about their larger-scale involvement and contributions to the scientific community. Thus, it makes sense that students who reported having a mentor had higher social-identity scores than those without a mentor in our study and others (e.g., Hernandez et al., 2017). Moreover, non-BUILD PODER students may have been in a mentored research laboratory, exposed to science social-identity concepts such as being seen as an authority or obtaining recognition. The BUILD PODER program's value-add was in science personal-identity; students could see themselves as scientists and belonging in science. This sense of belonging is critical in maintaining motivation through the racially charged structural and interpersonal challenges on top of rigorous science education.

A noteworthy post hoc finding has to do with the difference in scores between science personal-identity and social-identity. Although no statistical analysis was conducted, it is interesting to see how much greater the reports of science personal-identity 
are compared with the reports of science social-identity (see Figure 1). In terms of science identity development, this may suggest that the social component of science identity (i.e., recognition from others) may take a longer time to develop. These questions specifically assess the pursuits of scientists as they become more skilled and prominent, and these lower responses may reflect the realization and acknowledgment that they are emerging scientists.

The items for science social-identity may also reflect a bias in survey item interpretation, a long-standing concern among psychometricians, as survey items can be filtered through group identities and self-evaluation (Heine and Lehman, 1997; Chung et al., 2016). Research suggests that subjective norms in survey items are personalized by Latinx youth, who interpret collective social comparisons linked to people they know (e.g., siblings, parents) rather than a manufactured norm typically found in White youth (West et al., 2011; Carle et al., 2012). Thus, future research on this topic should consider both how such scientific pursuits grow over time with more training and experience (e.g., on-thejob training, graduate school training) and the survey item interpretation of these questions among varying ethnic-racial groups.

\section{Intention to Pursue a Science Career}

Latinx students who participated in BUILD PODER held stronger intention to pursue a science career at the end of college than Latinx students in the non-BUILD PODER groups (those with and without a mentor). This finding is noteworthy, because both science personal- and social-identity are crucial in motivating students to endure the rigor of preparing for a science career. Thus, this finding affirms that the CRT-informed program, BUILD PODER, is making strides in diversifying the biomedical workforce and supports the work of others who find that science identity is predictive of pursuing a career in science among URM students (Chemers et al., 2011; Estrada et al., 2011; Merolla et al., 2012; Stets et al., 2017).

Additionally, this finding supports previous work that having a faculty mentor alone may not be sufficient to retain URM students in the sciences (Chang et al., 2014; Hernandez et al., 2017; Vargas et al., 2020). Prior research has found that negative mentoring may contribute to the "push out" of undergraduate students, especially URM students. For example, a qualitative interview study of undergraduate life science researchers determined that negative mentoring can be demonstrated in seven ways: absenteeism, abuse of power, interpersonal mismatch, lack of career support, lack of psychosocial support, misaligned expectations, and unequal treatment (Limeri et al., 2019). These negative mentoring experiences are harmful to students' psychological well-being and are detrimental to their development as scientists. Many students felt that "they were not good enough to be scientists" (Limeri et al., 2019, p. 10), ultimately questioning their career choices as emerging scientists. Thus, the mere presence of a mentor may not be enough to retain students in science, especially if the mentorship experience is one where aspects of negative mentorship are present.

To retain Latinx students in the sciences to pursue science careers, we must acknowledge that Latinx students who choose a science career have unique structural, interpersonal, and intrapsychic experiences. When these students have access to a critically informed research program that is race conscious and less hierarchical, with mentors who are responsive and trained from a CRT perspective, Latinx students are immersed in an environment to thrive in the sciences. Students invited into the social justice possibilities of research are likely to develop innovations in research topics and methods that can resolve social problems and lead to greater education and health equity.

\section{Limitations}

Although we provide evidence that a CRT-informed undergraduate research experience successfully promotes science personal-identity and social-identity and intentions to pursue science careers, there are limitations to the current study. First, there is limited information about the types of science activities that the non-BUILD PODER students were engaged in and their engagement level. For example, there is a possibility that faculty trained by BUILD PODER may have mentored the non-BUILD PODER students who reported faculty mentorship (Non-BUILD PODER+M). Therefore, it is possible that a student (while not enrolled in BUILD PODER) had a mentor who was a recipient of our CRT-informed mentorship training and consequently received more culturally responsive mentorship.

A second limitation included our inability to examine science personal-identity and the intention to pursue a science-related research career in the first year of college. In contrast, science social-identity was able to be examined. Unfortunately, the Freshman Survey did not contain the three items assessing science personal-identity until Fall 2017 (see Stolzenberg et al., 2019). The question assessing the intention to pursue a science-related research career was not added until Fall 2016 (see Eagan et al., 2017). The recent inclusion of these items in the Freshman Survey will allow future studies to examine differences in first- and senior-year science personal-identity and the pursuit of a science-related research career.

A third limitation is the type of institution where the data were collected. CSUN is a Hispanic-serving institution (HSI), a federal designation wherein Hispanic students are at least 25\% of the enrolled full-time undergraduate student population. In fact, more than $50 \%$ of our student population identifies as Hispanic/Latinx. Thus, our students may be less likely to feel that they are the "only one" in science settings, which is a common problem for many URM college student scientists (e.g., Malone and Barabino, 2009). Investigating differences across types of institutions is an interesting area of research to pursue. With these limitations in mind, our findings provide compounding evidence that BUILD PODER, a CRT-informed undergraduate research experience, fosters science personal-identity and social-identity, as well as the intention to pursue a science career among Latinx students - a group that has been historically underrepresented and currently remains underrepresented in the sciences (NSF, 2019).

\section{Recommendations}

Our research highlights the importance of providing Latinx students majoring in the biomedical sciences with undergraduate research experiences founded on the belief that their diverse life experiences are essential, meaningful, and relevant to their development as scientists. Researchers, policy makers, and educators interested in fostering success in STEM among Latinx undergraduate students should consider adopting a CRT-informed curriculum into their research programs and research courses. Developing and integrating a curriculum rooted in 
culture, social justice, and empowerment may also help alleviate the cultural mismatch that Latinx students experience in undergraduate settings (e.g., Vasquez-Salgado et al., 2015).

We acknowledge that such programs take resources to develop and implement; thus, BUILD PODER is committed to publishing its CRT-informed curriculum for students and teachers in the future. We included the My Science Academic Pathway Pipeline activity (see Appendix in Supplemental Material) for students across diverse backgrounds to better understand academic disparities in STEM. Students will visually track individuals who share their characteristics (discipline, gender, ethnicity, disability) through higher education institutions to professional careers in the sciences. This activity, which uses the Women, Minorities, and Persons with Disabilities in Science and Engineering data provided by the NSF (2019), helps spark discussions about the importance of students finding supportive communities throughout each educational level along the academic pathway to reach their career goals. By employing a CRT-informed curriculum, we aim to strengthen the interest and intentions to pursue careers in the sciences for students of diverse and underrepresented backgrounds.

\section{ACKNOWLEDGMENTS}

Research reported in this publication was supported by the National Institute of General Medical Sciences of the National Institutes of Health under Award Numbers TL4GM118977 and RL5GM118975.

\section{REFERENCES}

Arnett, J. J. (2000). Emerging adulthood: A theory of development from the late teens through the twenties. American Psychologist, 55(5), 469-480.

Arnett, J. J. (2014). Emerging adulthood: The winding road from the late teens through the twenties. Oxford University Press.

Avila, A. (2019). Latinas as scientists: Positioning scientific identities bilingually. Theory Into Practice, 58(3), 209-216. https://doi.org/10.1080/00405841 .2019.1607655

Baird, M., Buchinsky, M., \& Sovero, V. (2016, October). Decomposing the racial gap in STEM major attrition: A course-level investigation (RAND Working Paper Series WR-1171). doi: http://dx.doi.org/10.2139/ssrn.2870049

Bell, D. A. (1995). Who's afraid of critical race theory? University of Illinois Law Review, 1995, 893-910

Bensimon, E. M., \& Dowd, A. C. (2012). Developing the capacity of faculty to become institutional agents for Latinos in STEM. Los Angeles, CA University of Southern California. Retrieved July 5, 2019, from https:// cue.usc.edu/files/2016/01/Bensimon_Developing-IAs_NSF-Report -CUE_2012.pdf

Berdan Lozano, J., \& Tilman, T. S. (2016, November). 2016 College Senior Survey. Retrieved July 5, 2019, from https://heri.ucla.edu/briefs/CSS/ CSS-2016-Brief.pdf

Brewer, M. B., \& Hewstone, M. E. (2004). Self and social identity. Malden, MA: Blackwell Publishing.

Burke, P. J., \& Hoelter, J. W. (1988). Identity and sex-race differences in educational and occupational aspirations formation. Social Science Research, 17(1), 29-47.

Byars-Winston, A., \& Rogers, J. G. (2019). Testing intersectionality of race/ ethnicity $x$ gender in a Socio-Cognitive Career Theory Model with science identity. Journal of Counseling Psychology, 66(1), 30-44. http:// dx.doi.org/10.1037/cou0000309

Carle, A. C., Weech-Maldonado, R., Ngo-Metzger, Q., \& Hays, R. D. (2012). Evaluating measurement equivalence across race and ethnicity on the CAHPS $®$ Cultural Competence survey. Medical Care, 50(9 Suppl 2), S32-S36.

Carlone, H. B., \& Johnson, A. (2007). Understanding the science experiences of women of color: Science identity as an analytic lens. Journal of Research in Science Teaching, 44(8), 1187-1218.
Chang, M. J., Eagan, M. K., Lin, M. H., \& Hurtado, S. (2011). Considering the impact of racial stigma and science identity: Persistence among biomedical and behavioral science students. Journal of Higher Education, 82(5), 564-597.

Chang, M. J., Sharkness, J., Hurtado, S., \& Newman, C. B. (2014). What matters in college for retaining aspiring scientists and engineers from underrepresented racial groups. Journal of Research in Science Teaching, 51(5), 555-580.

Chemers, M. M., Zurbriggen, E. L., Syed, M., Goza, B. K., \& Bearman, S. (2011) The role of efficacy and identity in science career commitment among underrepresented minority students. Journal of Social Issues, 67(3) 469-491.

Chung, J., Schriber, R. A., \& Robins, R. W. (2016). Positive illusions in the academic context: A longitudinal study of academic self-enhancement in college. Personality and Social Psychology Bulletin, 42(10), 13841401.

Cokley, K., Awad, G., Smith, L., Jackson, S., Awosogba, O., Hurst, A., ... \& Roberts, D. (2015). The roles of gender stigma consciousness, impostor phenomenon and academic self-concept in the academic outcomes of women and men. Sex Roles, 73(9), 414-426. https://doi.org/10.1007/ s11199-015-0516-7

Cokley, K., Mcclain, S., Enciso, A., \& Martinez, M. (2013). An examination of the impact of minority status stress and impostor feelings on the mental health of diverse ethnic minority college students. Journal of Multicultural Counseling and Development, 41(2), 82-95. https://doi org/10.1002/j.2161-1912.2013.00029.x

Cole, D., \& Espinoza, A. (2008). Examining the academic success of Latino students in science technology engineering and mathematics (STEM) majors. Journal of College Student Development, 49(4), 285-300.

Crenshaw, K. (1990). Mapping the margins: Intersectionality, identity politics, and violence against women of color. Stanford Law Review, 43, 1241 1299

Dika, S. L., \& D'Amico, M. M. (2016). Early experiences and integration in the persistence of first-generation college students in STEM and non-STEM majors. Journal of Research in Science Teaching, 53(3), 368-383.

Eagan, M. K., Stolzenberg, E. B., Zimmerman, H. B., Aragon, M. C., Whang Sayson, H., \& Rios-Aguilar, C. (2017). The American freshman: National norms Fall 2016. Los Angeles: Higher Education Research Institute, UCLA.

Ellemers, N., Spears, R., \& Doosje, B. (2002). Self and social identity. Annual Review of Psychology, 53(1), 161-186.

Estrada, M., Woodcock, A., Hernandez, P., \& Wesley, P. (2011). Toward a model of social influence that explains minority student integration into the scientific community. Journal of Educational Psychology, 103(1), $206-$ 222.

Fuligni, A. J. (2007). Family obligation, college enrollment, and emerging adulthood in Asian and Latin American families. Child Development Perspectives, 1(2), 96-100.

Hazari, Z., Sadler, P., \& Sonnert, G. (2013). The science identity of college students: Exploring the intersection of gender, race, and ethnicity. Journal of College Science Teaching, 42, 82-91.

Heine, S. J., \& Lehman, D. R. (1997). The cultural construction of self-enhancement: An examination of group-serving biases. Journal of Personality and Social Psychology, 72(6), 1268-1283.

Hernandez, P., Bloodhart, B., Barnes, R., Adams, A., Clinton, S., Pollack, I., ... \& Fischer, E. (2017). Promoting professional identity, motivation, and persistence: Benefits of an informal mentoring program for female undergraduate students. PLOS ONE, 12(11), E0187531.

Hernandez, P. R., Schultz, P. W., Estrada, M., Woodcock, A., \& Chance, R. C. (2013). Sustaining optimal motivation: A longitudinal analysis of interventions to broaden participation of underrepresented students in STEM Journal of Educational Psychology, 105(1), 89-107.

Hernandez, P. R., Woodcock, A., Estrada, M., \& Schultz, P. W. (2018). Undergraduate research experiences broaden diversity in the scientific workforce. BioScience, 68(3), 204-211.

Hurtado, S., Eagan, M. K., Cabrera, N. L., Lin, M. H., Park, J., \& Lopez, M. (2008). Training future scientists: Predicting first-year minority student participation in health science research. Research in Higher Education, 49(2), 126-152. 
Jackson, K. M., \& Suizzo, M. A. (2015). Sparking an interest: A qualitative study of Latina science identity development. Journal of Latina/o Psychology, 3(2), 103-120. https://doi.org/10.1037/lat0000033

Jones, M. T., Bariow, A. E. L., \& Villaregjo, M. (2010). Importance of undergraduate research for minority persistence and achievement in biology. The Journal of Higher Education, 87(1), 82-115. https://doi.org/10.1080/ 00221546.2010 .11778971

Katrevich, A. V., \& Aruguete, M. S. (2017). Recognizing challenges and predicting success in first-generation university students. Journal of STEM Education: Innovations \& Research, 18(2), 40-44.

Kim, A. Y., Sinatra, G. M., \& Seyranian, V. (2018). Developing a STEM identity among young women: A social identity perspective. Review of Educational Research, 88(4), 589-625. https://doi.org/10.3102/0034654318779957

Limeri, L. B., Asif, M. Z., Bridges, B. H. T., Esparza, D., Tuma, T. T., Sanders, D., ... \& Dolan, E. L. (2019). "Where's my mentor?!" Characterizing negative mentoring experiences in undergraduate life science research. CBE-Life Sciences Education, 18, 1-13. doi: 10.1187/cbe.19-02-0036

López, G. R. (2003). The (racially neutral) politics of education: A critical race theory perspective. Educational Administration Quarterly, 39(1), 68-94.

Lu, C. (2015). Finding los científicos within: Latino male science identity development in the first college semester. Journal of College Student Development, 56(7), 740-745. https://doi-org.libproxy.csun.edu/10.1353/ csd.2015.0069

Luhtanen, R., \& Crocker, J. (1992). A collective self-esteem scale: Self-evaluation of one's social identity. Personality and Social Psychology Bulletin, 18(3), 302-318.

Malone, K. R., \& Barabino, G. (2009). Narrations of race in STEM research settings: Identity formation and its discontents. Science Education, 93(3), 485-510. doi: https://doi.org/10.1002/sce.20307

Merolla, D. M., \& Serpe, R. T. (2013). STEM enrichment programs and graduate school matriculation: The role of science identity salience. Social Psychology of Education, 16(4), 575-597.

Merolla, D. M., Serpe, R. T., Stryker, S., \& Shultz, P. W. (2012). Structural precursors to identity processes: The role of proximate social structures. Social Psychology Quarterly, 75, 149-172.

National Science Foundation. (2019). Women, minorities, and persons with disabilities in science and engineering: 2019 (Special Report NSF 19-304). Alexandria, VA. Retrieved July 5, 2019, from www.nsf.gov/statistics/wmpd

Peteet, B., Brown, C., Lige, Q., \& Lanaway, D. (2015). Impostorism is associated with greater psychological distress and lower self-esteem for African American students. Current Psychology, 34(1), 154-163. https://doi. org/10.1007/s12144-014-9248-z

Rincon, B. E., \& George-Jackson, C. E. (2016). STEM intervention programs: Funding practices and challenges. Studies in Higher Education, 41(3), 429-444.

Robinson, K. A., Perez, T., Carmel, J. H., \& Linnenbrink-Garcia, L. (2019). Science identity development trajectories in a gateway college chemistry course: Predictors and relations to achievement and STEM pursuit. Contemporary Educational Psychology, 56, 180-192.

Robinson, K. A., Perez, T., Nuttall, A. K., Roseth, C. J., \& Linnenbrink-Garcia, L. (2018). From science student to scientist: Predictors and outcomes of heterogeneous science identity trajectories in college. Developmental Psychology, 54(10), 1977-1992.

Saetermoe, C. L., Chavira, G., Khachikian, C. S., Boyns, D., \& Cabello, B. (2017). Critical race theory as a bridge in science training: The California State University, Northridge BUILD PODER program. In BMC Proceedings, 11(12), 41-55. BioMed Central.

Schultz, P. W., Hernandez, P. R., Woodcock, A., Estrada, M., Chance, R. C., Aguilar, M., \& Serpe, R. T. (2011). Patching the pipeline: Reducing educational disparities in the sciences through minority training programs. Educational Evaluation and Policy Analysis, 33(1), 95-114.

Sellers, R. M., Smith, M. A., Shelton, J. N., Rowley, S. A., \& Chavous, T. M. (1998). Multidimensional model of racial identity: A reconceptualization of African American racial identity. Personality and Social Psychology Review, 2(1), 18-39. https://doi.org/10.1207/s15327957pspr0201_2

Seriki, V. D. (2018). Advancing alternate tools: Why science education needs CRP and CRT. Cultural Studies of Science Education, 13, 93-100.

Seymour, E., \& Hewitt, N. (1997). Talking about leaving: Why undergraduates leave the sciences. Boulder, CO: Westview Press.
Slovacek, S., Whittinghill, J., Flenoury, L., \& Wiseman, D. (2012). Promoting minority success in the sciences: The minority opportunities in research programs at CSULA. Journal of Research in Science Teaching, 49(2), 199-217.

Solórzano, D. G., Ceja, M., \& Yosso, T. J. (2000). Critical race theory, racial microaggressions, and campus racial climate: The experiences of African American college students. Journal of Negro Education, 69(1/2), 60-73.

Solórzano, D. G., \& Yosso, T. J. (2002). Critical Race methodology: Counter-storytelling as an analytical framework for educational research. Qualitative Inquiry, 8(1), 23-44.

Steele, C. M. (1997). A threat is in the air: How stereotypes shape intellectual identity and performance. American Psychologist, 52, 613-629. https:// doi.org/10.1037/0003-066X.52.6.613

Steele, C. M., \& Aronson, J. (1995). Stereotype threat and the intellectual test performance of African Americans. Journal of Personality and Social Psychology, 69(5), 797-811. https://doi.org/10.1037/0022-3514.69.5.797

Stephens, N. M., Fryberg, S. A., Markus, H. R., Johnson, C. S., \& Covarrubias, R. (2012). Unseen disadvantage: How American universities' focus on independence undermines the academic performance of first-generation college students. Journal of Personality and Social Psychology, 102(6), 1178-1197.

Stets, J. E., Brenner, P. S., Burke, P. J., \& Serpe, R. T. (2017). The science identity and entering a science occupation. Social Science Research, 64, $1-14$.

Stolzenberg, E. B., Eagan, M. K., Aragon, M. C., Cesar-Davis, N. M., Jacobo, S., Couch, V., \& Rios-Aguilar, C. (2019). The American Freshman: National Norms Fall 2017. Los Angeles: Higher Education Research Institute, UCLA.

Strayhorn, T. L., Long, L. L., III, Kitchen, J. A., Williams, M. S., \& Stentz, M. E. (2013, June). Academic and social barriers to Black and Latino male collegians' success in engineering and related STEM fields. Paper presented at: 2013 American Society of Engineering Education Annual Conference and Exposition (Atlanta, GA).

Tajfel, H. (1981). Human groups and social categories. Cambridge, UK: Cambridge University Press.

Tajfel, H., \& Turner, J. (1986). The social identity theory of intergroup behavior. In Worchel, S., \& Austin, W. (Eds.), Psychology of intergroup relations (pp. 7-24). Chicago, IL: Nelson Hall.

Thiry, H., \& Laursen, S. L. (2011). The role of student-advisor interactions in apprenticing undergraduate researchers into a scientific community of practice. Journal of Science Education and Technology, 20(6), 771784. https://doi.org/10.1007/s10956-010-9271-2

Thiry, H., Laursen, S. L., \& Hunter, A.-B. (2011). What experiences help students become scientists? A comparative study of research and other sources of personal and professional gains for STEM undergraduates. Journal of Higher Education, 82(4), 357-388.

Thompson, J. J., \& Jensen-Ryan, D. (2018). Becoming a "science person": Faculty recognition and the development of cultural capital in the context of undergraduate biology research. CBE-Life Sciences Education, 17(4), ar62.

U.S. Census Bureau (2018, October). 2017 National population projections and vintage 2017 population estimates. Retrieved July 5, 2019, from www.census.gov/library/visualizations/2018/comm/hispanic-projected - pop.html

van Ryn, M., Hardeman, R., Phelan, S. M., Burgess, D. J., Dovidio, J. F., Herrin, J., ... \& Przedworski, J. M. (2015). Medical school experiences associated with change in implicit racial bias among 3547 students: a medical student CHANGES study report. Journal of General Internal Medicine, 30(12), 1748-1756. https://doi.org/10.1007/s11606-015-3447-7

Vargas, J. H., Saetermoe, C. L., \& Chavira, G. (2020). Using critical race theory to reframe mentor training: Theoretical considerations regarding the ecological systems of mentorship. Higher Education (online). https:// doi.org/10.1007/s10734-020-00598-z

Vasquez-Salgado, Y., Greenfield, P. M., \& Burgos-Cienfuegos, R. (2015) Exploring home-school value conflicts: Implications for academic achievement and well-being among Latino first-generation college students. Journal of Adolescent Research, 30(3), 271-305

West, J. H., Hall, P., Thygerson, S. M., Edwards, E. S., Bennion, S. R., \& Bennet C. (2011). Hispanic adolescents' behavioral intentions to avoid texting while driving. American Journal of Health Studies, 26(1), 37-44. 